\title{
The Description of 12th Grade Students' Conception of Electromagnetics
}

\author{
Rendy Wikrama Wardana \\ Science Education Postgraduate School \\ Indonesia University of Education \\ Bandung, Indonesia \\ rendy86.upi@gmail.com
}

\author{
Paulus Cahyono Tjiang \\ Science and Information Technology Department \\ Parahyangan Catolic University \\ Bandung, Indonesia \\ pctjiang@unpar.ac.id
}

\author{
Liliasari \\ Science Education Postgraduate School \\ Indonesia University of Education \\ Bandung, Indonesia \\ liliasari@upi.edu
}

Nahadi

Science Education Postgraduate School Indonesia University of Education

Bandung, Indonesia

Nahadi@upi.edu

\begin{abstract}
Electromagnetic concepts are abstract, difficult and complex concepts. There are different conceptions understood by students in learning electromagnetic concept. This study aims to identify and describe the conception of high school students who have been studying electromagnetic. Descriptive method used in this research. The subjects consist of 27 respondents of 12th grade students. The data collection done by providing an essay test instruments referred to test models of Electromagnetism Concept Inventory (EMCI) those includes subconcepts of Electrostatic, Magnetism, Electromagnetic induction and Electromagnetic waves. The result of data analysis shows that only $2 \%$ of respondents answered correctly on the subconcepts of magnetism. In other sub-concepts there were no respondents who answered correctly. Moreover, the conceptions understood by respondents about electromagnetic concept were very diverse.
\end{abstract}

Keywords- conception; 12th grade students; electromagnetic concept

\section{INTRODUCTION}

Conceptual knowledge is an essential part of students' conception in studying physics. Therefore, they could be solving problems concerning the physical phenomena in everyday life. Some researches on physics teaching indicate that the concept of physics is a difficult, abstract and complex. Educators, teachers and professors often have difficulty in conveying information about physics concepts to the students. This is due to the diversity of conceptions understood by students. The conception is mental representations of the individual or learners to a concept [1]. Then as summarized defined conception as an ability to understand the concepts, either gained through interaction with the environment as well as the concept gained from formal education [2]. The diversity of conceptions in learning physics due to the characteristics of the concept of physics was difficult, abstract and complex. One of the topics in physics which has such an abstract, difficult and complex concept is Electromagnetic.

The abstract concept of Electromagnetic is a concept which phenomena can be measured and observed, but the process in each of these phenomena is difficult to observe. Electricity and magnetism for secondary schools were generally taught using mathematical formulas based on the concept of energy and the use simple lab. The knowledge of electromagnet is the fundamental of the application of the latest technologies applied in the operation of various electronic devices, such as radio, television, electric motor, remote sensors, computers, and other electronic devices [3].

A research conducted indicated that the concept of Electromagnets was a difficult concept [4]. Later research showed that the difficulties that most students face in learning electric and magnet concept remains the same prior to and after learning [5]. This was due to the concept which abstract and complex. The electric potential, electric potential energy and electromagnetic induction are materials considered difficult by students from various countries in the study of electromagnet [6]. This was supported by research that showed students have difficulty in learning concept of electromagnetic induction [7]. This was because the students need to understand the basic concepts of electromagnetic such as electric field, magnetic field, the flux and the electromagnetic force. Further research [8 and 9] stated that the concept of electromagnetic induction was a difficult concept. This was due to the diversity of alternative conceptions understood by students about the concept of electromagnetic induction.

Some researches showed that in addition to the concept of electric potential, electric potential energy and electromagnetic 
induction were also considered difficult by students in studying Electromagnetic. A research showed that Faraday's Law was a difficult topic to understand by students in order to understand Electromagnetic [3]. The difficulty faced by students in Faraday's Law was an integral form that involves the concept of flux. In learning flux, the students must understand the concept learned in Gauss's Law, therefore they should be recalled these concepts when learning Faraday's Law. In addition, a research [10] stated that the respondents had difficulties in when did they use Biotsavart's law in solving magnetic dipoles problems and the magnetic field of the electric current in the loop. In addition, further research which also done [11] stated that a better understanding is needed by students in learning the basic topics of Electromagnetic such as Gauss's law, electric current and electric potential.

Several other studies have shown that other difficulties experienced by students, besides the concept of Electromagnets itself, were as follow: A study stated that one of the difficulty experienced by students when they have to understand the meaning of Electromagnetic concept [12]. The definition of an idea of a concept did not only provide an explanation about the meaning, but also why and how the concept occurs. Furthermore, a research [13] proved that the use of mathematical operations affects the activity of learning Physics. This means that one of the difficulties experienced by students in studying Electromagnets was the use of various mathematical operations - such as integral, differential and so forth. Supporting the result of the research [13 and 14] also affirmed that the difficulties experienced by students in studying Electromagnets was the use of mathematical operations and its integration to the concept of Electromagnets. Moreover, other research [8] conducted and claimed that various alternative conceptions understood by students in studying Electromagnets strain them from fully understanding the concept itself.

Based on descriptions above, the problem of this research was how the conception understood by high school students who have studied Electromagnetic? In accordance to the problem, the purpose of this study was to identify and described the conception of $12^{\text {th }}$ grade students who have studied Electromagnetic. The results of this study were expected to be used as an input and consideration in studying Electromagnetics.

\section{RESEARCH METHOD}

The method used in this research was a descriptive method. The subjects of the research consist of 27 high school students of $12^{\text {th }}$ grade. The data collection done by providing an essay test instruments refer to test models of Electromagnetism Concept Inventory (EMCI). This test was used to obtain the respondents conceptions that have been learned the concept of Electromagnetics. EMCI test includes four sub-concepts: Electrostatics, Magnetism, Electromagnetic induction and Electromagnetic waves. A rubric scale on the answer sheet respondents was used in order to analyze the data. Scale of 0 indicated that the students did not answer the question or they rewrite what was known in the questions and answer simply by repeating the questions. Scale of 1 indicated that the students' answers and reasoning were incorrect. Scale of 2 shows that if the answer was correct with incorrect reasoning or the answer was incorrect with correct reasoning. Scale of 3 showed that both the students' reasoning and answered were correct.

\section{RESULTS AND DISCUSSION}

A total of 27 students were involved in this study to take a test about the concept of Electromagnetics. The data was obtained by providing a test in essay form. The test consists of 8 questions; each 2 questions are about sub-concepts: Electrostatics, Magnetism, Electromagnetic Induction and Electromagnetic Waves. The data was analyzed by using a rubric scale of respondents to each question. TABLE I showed the percentage of conceptions of high school students who have learned the concept of Electromagnetic.

Based on the data in Tabel I, there are $4 \%$ of students who did not answered some questions, but in general, most students answered the questions given. It can be stated that the average test result is that only $2 \%$ of students answered correctly (Scale 3). Other $68 \%$ of students answered on a scale of 1 and $26 \%$ answered on a scale of 2 . This indicates that the majority of students' answers were incorrect. The data also showed that there were $100 \%$ of students answered incorrectly on the question about induction and electromagnetic waves.

TABLE I. THE PERCENTAGE OF CONCEPTIONS OF HIGH SCHOOL STUDENTS WHO HAVE LEARNED THE CONCEPT OF ELECTROMAGNETIC BASED ON THE STUDENTS' ANSWERS

\begin{tabular}{|c|c|c|c|c|c|c|}
\hline \multirow[t]{2}{*}{ Sub-Concepts } & \multirow{2}{*}{$\begin{array}{c}\text { Number } \\
\text { Test }\end{array}$} & \multicolumn{4}{|c|}{$\begin{array}{c}\text { \% Answers for each } \\
\text { Category }\end{array}$} & \multirow{2}{*}{$\begin{array}{c}\text { \% Average } \\
\text { of Correct } \\
\text { Answers }\end{array}$} \\
\hline & & 0 & 1 & 2 & 3 & \\
\hline \multirow[t]{2}{*}{ Electrostatics } & 1 & 4 & 96 & - & - & \multirow{2}{*}{0} \\
\hline & 2 & 11 & 89 & - & - & \\
\hline \multirow[t]{2}{*}{ Magnetism } & 3 & 7 & 19 & 74 & - & \multirow[b]{2}{*}{9} \\
\hline & 4 & 4 & 37 & 41 & 18 & \\
\hline Electromagnetic & 5 & - & 100 & - & - & \multirow[b]{2}{*}{0} \\
\hline Induction & 6 & 4 & 96 & - & - & \\
\hline Electromagnetic & 7 & - & 100 & - & - & \multirow{2}{*}{0} \\
\hline Waves & 8 & - & 7 & 93 & - & \\
\hline Total Average (\%) & & 4 & 68 & 26 & 2 & 2 \\
\hline
\end{tabular}

Students who answered incorrectly showed the diversity of conception and difficulties experienced by students in the concept of Electromagnets. The incorrectly answere in electrostatics sub-concept generally reffer to: electric potential formula acording to resultant, electric field depends on electrical potential since electric potential does not exist so the electric field is a zero, electric potential energy is not affected by electric field, the direction of electric force opposite to energy source, the direction of in force to $(+)$ and out force to (-). In magnetism sub-concept, Students' who answered incorrectly reffer to: when magnet devide in two part it become one pole, the magnet pole are found by rubbing and induction, north and south pole become unclear, north pole is above the earth and south pole is under the earth, north pole symbolized by blue colour and south pole symbolized by red colour.

Students' who answered incorrectly on electromagnetic induction sub-concept reffer to: magnet has transfer power is $(+)$ and the charge of coil is (-), the direction of galvanometer 
pointer is in the same direction with magnet motion, irish cousing electric force, electricity and magnet field can change the direction, make area biger, the fluks in area become smaller, and it use electric force formula. In electromagnetics wave, Students' who answered incorrectly reffer to : if there is a coil, a number of coil, electric current and magnetic field, when having polarization indication, whwn some body listens to the radio, the moving electron will cousing electric and magnet field when it spread, while the electric and magnet field move perpendicular to each other, the students use the wrong formula to understand the distance and velocity, and the students only write the final result (not the proscess). The result of this research turned out to be relevant to the result of research [8] which stated that students have various conceptions about Electromagnets. The result that showed the difficulties experienced by respondents in studying Electromagnetics was relevant to the research [6] which indicated that the difficulties faced by students in studying Electromagnets remain the same before and after learning.

This study showed only $2 \%$ of students correctly answered the sub-concept about Magnetism, its means that Magnetism are considered difficult by students. This result was confirmed by the result of research conducted by reference [10] whose stated that the difficulties experienced by students in Magnetism was about the use of Biotsavart's law in solving problems about magnetic dipoles and magnetic poles from electric current in the loop.

The result of data analysis showed that $100 \%$ of students answered incorrectly on the sub-concept of induction and electromagnetic waves. The difficulties faced by students in studying sub-concepts of Electromagnetic were relevant to the result of some previous studies including a research which states that electromagnetic induction is a material considered difficult by students from various countries in the study of Electromagnetics [6]. This was supported by a research [7] that also showed that the students have difficulties in learning the concept of electromagnetic induction. Further research conducted by reference [ 8 and 9] stated that the concept of electromagnetic induction was a difficult concept. In addition to the sub-concept of electromagnetic induction, students were also found it difficult in learning electromagnetic waves. These difficulties were experienced by the students in answering conceptual questions or questions about the process of electromagnetic waves. This was due to the material characteristics of electromagnetic waves taught at school that emphasizes the mathematical formulation and application of electromagnetic waves in the daily life instead of interpreting every process that occurs in electromagnetic waves.

Based on the data from TABLE I, it shows that $26 \%$ of students' answers on magnetism and electromagnetic waves were categorized on a scale of 2 . In TABLE II, there was a description of the students' conceptions which were categorized on a scale of 2

Based on the Table II, most students answered correctly about magnets, however they still give wrong reasons. Basic all their concepts were constructed. This can be seen by their concept in answering the questions. At the sub-concept of electromagnetic wave category, most students gave wrong answers. However, their reason or equation formulation for the answer was right. The reason why their answered those students though that the spreading of electromagnetic wave two times, so the students multiply the equation. There were also students who did not answered. Based on that, it could be seen that students understood the mathematic formulation easier rather than its concept that has been showed from the previous questions. It was relevant with research which states that in term of solving electromagnetic problem, students easily answer mathematics problem rather than concept problem [15]. Furthermore, this result also relevant with educational concept at high school which was focus more on using mathematics formulation based on the basic concepts and practices.

TABLE II. CONCEPT DESCRIPTION ON STUDENTS ANSWER AT SCALE 2

\begin{tabular}{|c|c|c|c|c|}
\hline \multirow{2}{*}{$\begin{array}{l}\text { Sub } \\
\text { Con- } \\
\text { cept }\end{array}$} & \multirow{2}{*}{$\begin{array}{l}\text { Number } \\
\text { Test }\end{array}$} & \multirow{2}{*}{$\begin{array}{l}\text { Category } \\
\text { Scale } 2\end{array}$} & \multicolumn{2}{|c|}{$\begin{array}{c}\text { The Description of Conception } \\
\text { Answer }\end{array}$} \\
\hline & & & $\begin{array}{c}\text { The } \\
\text { Correct } \\
\text { Answer }\end{array}$ & Students Answer \\
\hline $\begin{array}{l}\text { Mag- } \\
\text { netic }\end{array}$ & 3 & $\begin{array}{l}\text { Right } \\
\text { answer, } \\
\text { wrong } \\
\text { reason }\end{array}$ & $\begin{array}{l}\text { It is still } \\
\text { magnet } \\
\text { because } \\
\text { every } \\
\text { magnetic } \\
\text { domain has } \\
\text { it magnetic } \\
\text { character }\end{array}$ & $\begin{array}{l}\text { Students answer about } \\
\text { magnet. However, } \\
\text { their reasons are still } \\
\text { wrong. The reasons } \\
\text { they give are about the } \\
\text { magnetic construction, } \\
\text { contain become more } \\
\text { less, the magnetic } \\
\text { power and its } \\
\text { character also } \\
\text { decrease. }\end{array}$ \\
\hline $\begin{array}{l}\text { Mag- } \\
\text { netic }\end{array}$ & 4 & $\begin{array}{l}\text { Right } \\
\text { answer, } \\
\text { wrong } \\
\text { reason }\end{array}$ & $\begin{array}{l}\text { South } \\
\text { magnetic } \\
\text { pulse will } \\
\text { be pulled } \\
\text { by the north } \\
\text { magnetic } \\
\text { pulse and } \\
\text { vice versa. }\end{array}$ & $\begin{array}{l}\text { Students basically } \\
\text { answer correctly; } \\
\text { magnetic field on } \\
\text { Earth is pointing to the } \\
\text { north and south of the } \\
\text { Earth. However, the } \\
\text { reasons are still wrong. } \\
\text { The reason they give } \\
\text { about this are; there } \\
\text { are magnetic fields at } \\
\text { north and south Earth, } \\
\text { there is a magnetic } \\
\text { force from north and } \\
\text { south, of the Earth is } \\
\text { the center of the Earth, } \\
\text { magnetic pulse has the } \\
\text { same direction with } \\
\text { Earth's pulse and } \\
\text { magnetic direction }\end{array}$ \\
\hline $\begin{array}{l}\text { Elec- } \\
\text { trom } \\
\text { agne } \\
\text {-tic } \\
\text { wave }\end{array}$ & 8 & $\begin{array}{l}\text { wrong } \\
\text { answer, } \\
\text { right } \\
\text { reason }\end{array}$ & $\begin{array}{l}\text { Equation: } \\
\mathrm{t}=\frac{s}{v} \\
\text { as } \mathrm{v}=\mathrm{c} \\
\text { then the } \\
\text { equation } \\
\text { will be: } \\
\mathrm{t}=\frac{s}{c} \\
\text { as the } \\
\text { result: } \\
\text { second }\end{array}$ & $\begin{array}{l}\text { Majority of the } \\
\text { students uses equation } \\
\text { like this: } \\
t=\frac{s}{v} x 2 \\
\text { as the result, } \\
\text { respondents answer: } \\
\qquad \text { or } \\
\text { Furthermore, the } \\
\text { respondent didn't } \\
\text { finish the mathematic } \\
\text { problem. }\end{array}$ \\
\hline
\end{tabular}




\section{CONCLUSION}

Based on the result and discussion of this research, the conclusions were: $12^{\text {th }}$ graduate students conception were diverse, few of student compre hendle ectromagnetic concepts, and no students understand about induction and electromagnetic wave sub-concept.

It is recommended for teachers should be changing their students' perspective. In the learning physics process, it is important not just focus on mathematics formulation but also at the physics processes itself.

\section{References}

[1] R. Duit, and D. Treagust, Conceptual change: A powerful framework for improving science teaching and learning, International Journal of Science education, 25(6), pp. 671-688, 2003.

[2] D. Finatri, Analisiskonsepsi guru padakonseplarutanditinjaudarirepresentasi level mikroskopik, Tesis, 2007.

[3] R. Chabay and B. Sherwood, Restructuring the introductory electricity and magnetism course, American Journal of Physic, 74(4), pp. 329-336, 2006.

[4] D.P. Maloney, T.L. O'Kuma, C.J.Hieggelke, and A.V. Heuvelen, Surveying students' conceptual knowledge of electricity \& magnetism, American Journal of Physics, S 69(7), pp. 12-23, 2001

[5] M. Planinic, Assessment of difficulties of some conceptual areas from electricity and magnetism using the conceptual survey of electricity and magnetism, American Journal of Physics, 73(12), pp. 1143-1148, 2006.

[6] M. Saglam and R. Millar, Upper high school students' understanding of electromagnetism, International Journal of Science Education, 28(5), pp. 543-566, 2006.

[7] J. Guisasola, J.M. Almudi, and K. Zuza, University students understanding of electromagnetic induction, International Journal of Science Education, (1), pp. 1-26, 2011

[8] B.G. Dega, J. Kriek and T.F. Mogese, Categorization of alternative conceptions in electricity and magnetism: The case of Ethiopian undergraduate students, Journal Research in Science Education, doi:10.1007/s11165-012-9332-z, 2012.

[9] B.G. Dega, J. Kriek and T.F. Mogese, Students' Conceptual Change in electricity and magnetism using simulations: A comparison of cognitive perturbation and cognitive conflict, Journal of Research in Science Teaching, 50 (6), pp. 677-698, 2013.

[10] V.S. Chasteen, E.R .Pepper, D.M. Caballero, S.J. Pollock and K.K. Perkins, Colorado upper-division electrostatics diagnostic: A conceptual assessment for the junior level, Physic Education Research, DOI: 10.1103/PhysRevSTPER.8.020108, 2012.

[11] V.S. Chasteen, E.R. Pepper, S.J. Pollock and K.K. Perkins, Thinking like a physicist: A multi-semester case study of junior-level electricity and magnetism, Physic Education Research, Doi./10.1119/1.4732528, 2012.

[12] N. Finkelstein, Learning physics in context: A study of student learning about electricity and magnetism, International Journal of Science Education, 27(10), pp. 1109-1187, 2005.

[13] J. Leppavirta, The impact of mathematics anxiety on the performance of students of electromagnetic, Journal of Engineering Education, 100 (3), pp. 424-443, 2011.

[14] E.R. Pepper, V.S. Chasteen, S.J. Pollock, and K.K. Perkins, Observations on student difficulties with mathematics in upper-division electricity and magnetism, Physic Education Research, DOI: 10.1103/ Phys Rev STPER.8.010111, 2012.

[15] T. Gok, The impact of peer instruction on college student's beliefs about physics and conceptual understanding of electricity and magnetism, International Journal of Science and Mathematics Education. 10: 417Y436, 2012. 